\title{
T and B Cells Immune Response and the importance of vaccines Against SARS-CoV-2
}

School of Biological Science and Engineering, Yachay Tech University, Hacienda San José s/n, San Miguel de Urcuquí 100119, Ecuador.

Corresponding author: ronny.ordonez@yachaytech.edu.ec

\begin{abstract}
SARS-CoV-2 has become a global pandemic because it is a severe respiratory syndrome that attacks many people worldwide and can lead to death depending on the severity. In recent years, the study of the acquired immune response (T cells) and innate (B cells) has increased to better treat the disease from the quantitative cell count. A picture has begun to emerge revealing that CD4+ T cells, CD8+ T cells, and neutralizing antibodies contribute to the control of SARS-CoV-2 in COVID-19 cases. This work studies the three fundamental components of the adaptive immune system: B cells (the source of antibodies), CD4+T cells, and CD8+T cells and their function against SARS-CoV2. The importance of vaccines and the different types of existing vaccines are discussed. Implications of covid-19 variants on Immunity and vaccine types are also analyzed to understand how the action of the immune system will help treat the disease.
\end{abstract}

Key words: Vaccine, B cells, CD4+, CD8+, SARS-CoV-2.

\section{Introduction}

Coronaviruses have been present within the human population for generations. Severe acute respiratory syndrome coronavirus 2 (SARS-CoV-2) is now the third of Betacoronavirus genus transferred to humans in the last twenty years. It has reported the highest contagiousness but the lowest mortality rate ${ }^{1}$. It emerged in China in December 2019. From that point on, it would mark the beginning of a pandemic that would affect millions of people worldwide due to its high transmissibility $^{2}$.

Covid-19, resulting disease from SARS-CoV-2, presents common clinical manifestations for most patients, which are fever, cough, and a grave "flu" that can evolve into respiratory distress (ARDS), pneumonia, renal failure, and death ${ }^{3}$. It has also been demonstrated that it can present post-Covid-19 complications, such as myocardial inflammation, arrhythmia, pneumothorax, and pleural effusion ${ }^{4}$. The meta-analysis carried out in January 2021 has shown that SARS-CoV-2 is most contagious when symptoms appear, but this contagiousness decreases to almost zero after ten days in mild-moderately ill patients. The same study suggests that it has a mean incubation period of 6.38 days, a time that can be considered relatively short if we take into account that the adaptive response takes between 15 and 21 days ${ }^{5}$. Once the virus enters the body and the innate immune response fails, the second line of defense, the adaptive immune system, is put into action thanks to the dendritic cells, which carry the virus antigen to the CD4+ $T$ cells (helper $T$ cells) ${ }^{6}$. These cells are responsible for triggering the humoral and cellular responses. This first response is in charge of defending the extracellular space through the action of antibodies produced by B cells ${ }^{7}$. The second one is focused on killing the virus in the intracellular space through the activity of CD8+ T cells (cytotoxic T cells). These cells are of particular interest in this review because after people get infected with SARS-CoV-2, they tend to generate CD8+ T cells that can target more than 15 distinct fragments of coronavirus proteins inside the infected cells giving them more protection to new variants. In contrast to B cells antibodies, which target the spike protein on the virus's surface, a protein that is susceptible to mutating ${ }^{8}$.

\section{T Cells Response}

Knowing about the adaptive response to certain diseases is essential for creating vaccines; in this case, it is necessary to understand how this response works against SARS-Cov-2. The first step for such an understanding is quantifying the virus-specific CD4+ and CD8+ T cells ${ }^{9}$. T cells primarily react to the spike protein on the coronavirus to initiate antiviral immunity ${ }^{10}$. In addition, depending on the patient and the severity of SARS-Cov-2, the immune response of $T$ cells can range from optimal to suboptimal. Over the years, the population of naïve $T$ cells has declined. Still, conversely, antigen-experienced memory $T$ cells become an essential part of the T cell population due to their memory system ${ }^{11,12}$. The older the person, the better the immune response to previously exposed pathogens.

On the contrary, T cells are easier to educate against new pathogens in children. For this reason, it has been observed that children who become infected are not significantly affected by the disease $\mathrm{e}^{11}$. Furthermore, $\mathrm{CD} 4+\mathrm{T}$ cells stimulate $\mathrm{B}$ cells to produce viral-specific antibodies and cytotoxic CD8+T cells to target virus-infected cells ${ }^{10}$. In addition, activated CD4+ and CD8+ T cells have been found to help both clearances of the acute infection caused by the disease and protective

Citation: Ordoñez R, Solano D , Granizo G. T and B Cells Immune Response and the importance of vaccines Against SARS-CoV-2. Revis Bionatura 2022;7(1). 36. http://dx.doi.org/10.21931/RB/2022.07.01.36

Received: 2 January 2021 / Accepted: 13 February 2022 / Published: 15 February 2022

Publisher's Note: Bionatura stays neutral with regard to jurisdictional claims in published maps and institutional affiliations. 
immunity against reinfection by establishing immunological memory against the pathogen ${ }^{13}$.

\section{CD4+ T}

CD4+ $T$ cells are central organizers of antiviral immune responses. Furthermore, some of the functions of CD4+ $T$ cells in SARS-CoV-2 infection are their ability to differentiate into various helper and effector cell types. This serves different actions: it helps CD8+ T cells, instructs B cells, recruits innate cells, has direct antiviral activities, and facilitates tissue repair $^{14}$ (Figure 1 ). In situations of uncontrolled immune or inflammatory responses, CD4+ $T$ cells can cause pathology ${ }^{15}$. Different studies have made it possible to find CD4+ T cells that are reactive against SARS-CoV-2 in patients who have not suffered from the disease, which is suggested according to Bacher. P., et al (2020) arise in response to infection by the common cold coronavirus (CCCoV) ${ }^{16}$. In addition, a correlation between the reappearance of CD4+ T cells and the patient's recovery has been observed when the patient has a severe SARS-CoV-2 infection ${ }^{17}$. This suggests that the patient's cells have already acquired some immunity against SARS-CoV-2 and give them protection against the disease, which causes them to recover.

\section{CD8+ T}

Through the literature, it can be known that CD8+ T cells have an essential role in eliminating viral infections. Activated CD8+ T cells have been found to display a wide range of cytotoxic molecules, which appear in the blood of infected patients before they recover from the disease ${ }^{18}$. In SARS$\mathrm{CoV}-2$ infections, the presence of virus-specific CD8+T cells has been associated with better Covid-19 outcomes ${ }^{19}$. This is because immunodominance is one of the main characteristics of the responses of CD8+ T cells in viral infections. According to Peng, they knew how CD8 T cells could better attack the disease of interest. $Y$ et al. 2021, knowing this characteristic will be essential for the design of vaccines to obtain optimal responses from CD8+ T cells ${ }^{20}$. Overall, circulating SARS-CoV2-specific CD8+T cells are less consistently observed than CD4+T cells ${ }^{21}$

Furthermore, Activated T cells directed toward spike (S), nucleo-capsid (N), membrane $(M)$, and other types of open reading frames can be detected in approximately $70 \%$ of acute and convalescent Covid-19 patients ${ }^{9}$. This is possible observed utilizing human leukocyte antigen (HLA) class I and II predicted peptide "mega pools" to stimulate peripheral blood mononuclear cells (PBMCs) of the patient 22 (Figure 2)

\section{SARS-CoV-2}
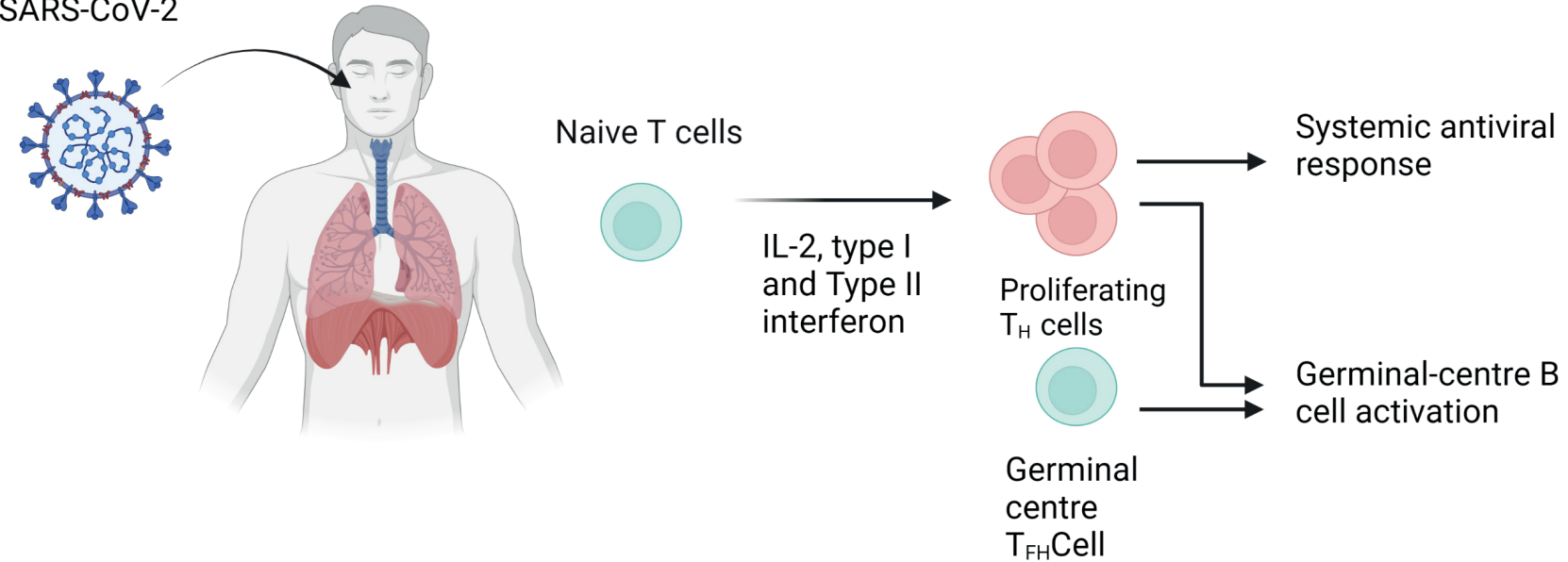

Figure 1. CD4+ T cell response during Covid-19. We can see how the virus enters the organism, which can happen differently. Later we can see how a naive T cell acts, the cell has contact with the interferon type I and types II, after the contact, we can see that there is a proliferation of $\mathrm{T} \mathrm{DH}$ cells which can activate the antiviral response system, or they can join Germinal Centre T cells, to generate the activation of Germinal-center B cells. BioRender (https://biorender.com/).

\section{SARS-CoV-2}

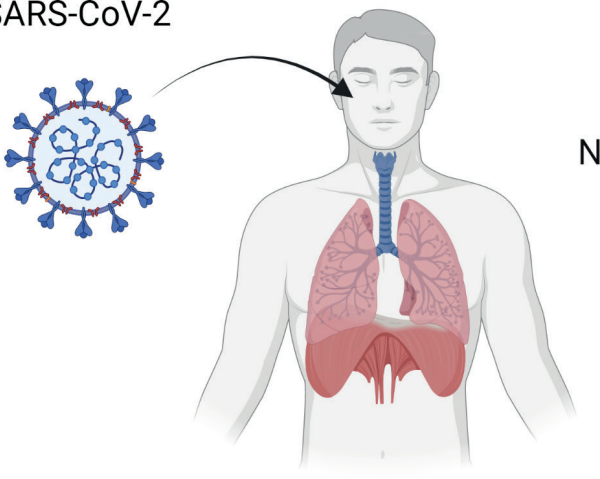

Naive T cells

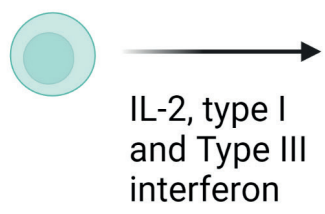

\section{Activvated T cells}

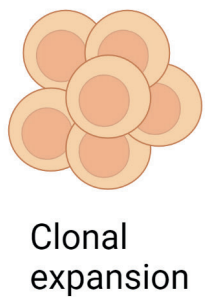

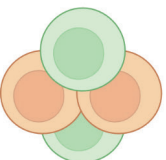

Effector T cells and terminally differentiated T cells

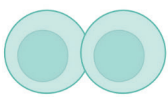

Memory T cells

Figure 2. CD8+ T cell response during Covid-19; We can see how the virus enters the organism, which can happen differently. Later we can see how a Naive T cell acts, the cell has contact with type I and Type III interferon, after the contact, we can see that there is an activation of T cells, which can produce effector T cells and terminally differentiated T cells or they can produce memory T cells to attack the virus. BioRender (https://biorender.com/). 


\section{B cells}

The Immune system has numerous ways to detect and avoid the return of infectious pathogens. It selects $B$ cells to produce antibodies that bind to the virus. It also extracts a store of memory $B$ cells that jumps into action if the virus attacks again ${ }^{23}$. B cells are just as crucial as $T$ cells within the immune system because they produce antibodies that trap specific invading viruses. These pathogen-specific B cells are induced to differentiate and secrete their antigen receptors into the blood in the form of antibodies ${ }^{24}$. These antibodies circulate throughout the body and bind to the pathogen that triggers the response wherever it occurs ${ }^{25}$. Thus, B cells play a critical role in the innate immune response against bacterial and viral diseases ${ }^{26,27}$. All would-be invaders have their compatible pre-existing $B$ and $T$ cells ready to respond when needed during the immune response. This is because each $B$ cell and $T$ cell expresses on its surface an antigen receptor that is different from all the others ${ }^{28}$.

It is essential to highlight that one of the immune system's most effective protection methods is the secretion of high-affinity antibodies. As the infection progresses in our body, the antibodies improve their affinity for the antigen, and the isotope class changes (immunoglobulin [lg]M, $\lg G, \lg A, \lg E)^{25}$. This process allows for the neutralization of pathogens and a better binding of antibodies ${ }^{29}$. The isotype is the part of the antibody that does not bind antigen directly but triggers other immune effector functionalities, such as activating the complement cascade or binding to receptors on immune cells to guide responses to pathogens ${ }^{30,31}$. Persistent antibody evolution occurs in germinal centers. This process requires that $B$ cells are exposed to antigens trapped in immune complexes on follicular dendritic cells ${ }^{32}$. Improvements in B-cell affinity occur in germinal centers (GCs), which develop in secondary lymphoid organs, for example, lymph nodes and the spleen. GCs are developed after the immune challenge and are essential for immunological memory production ${ }^{33}$ (Figure 3).

Spike and nucleocapsid are the primary antigens tested for seroconversion ${ }^{34}$. In Covid-19 cases. the Spike protein tar- gets $>90 \%$ of neutralizing antibodies, some of them targeting the N-terminus ${ }^{35,36}$. The study developed by Gaebler et al. demonstrates that during the first six months after infection, the anti-SARS-CoV-2 memory B cell response evolves. This process occurs with the accumulation of somatic lg mutations and the production of antibodies with greater amplitude and neutralizing power ${ }^{24}$.

The neutralizing antibodies are produced by $\mathrm{B}$ cells and are developing rapidly in most SARS-CoV-2- infected people, on the same time frame as seroconversion ${ }^{36}$. Understanding the conditions under which an antibody neutralizes SARSCoV-2 is necessary to predict immunity after infection or vaccination. When SARS-CoV-2 infection is severe, GC formation is impaired, affecting affinity maturation and memory quality and quantity, but it is unclear whether this occurs in mild or asymptomatic infections ${ }^{35}$. However, the antibody structure required to neutralize SARS-CoV-2 may not be particularly complex, as some of the reported neutralizing antibodies contain few mutations and embryos in a relatively short time. Therefore, it is suggested that they can be generated in GC relatively quickly ${ }^{37,38}$.

Studies suggest that various monoclonal antibodies with exquisite virus-neutralizing activity are promising candidates for development as modalities to treat or prevent SARS-CoV-2 infection (Figure 4$)^{39,40}$. In addition, the use of monoclonal studies against the respiratory syncytial virus (RSV) ${ }^{41}$ and for Ebo$\mathrm{la}^{42,43}$ has been registered.

\section{Implications of Variants on Immunity and Vaccines}

Variants occur through naturally produced nucleotide changes in the viral genome during replication, and these changes develop faster in RNA viruses than in DNA viruses ${ }^{44}$. Coronaviruses, however, make fewer mutations than most RNA viruses because they encode an enzyme that corrects some of the errors made during replication ${ }^{45}$. SARS-CoV-2 variants of concern (VOC) pose a threat: divergent strains with an accumulation of mutations in the different $\mathrm{S}$ domains can evade infection or vaccination-induced neutralizing antibodies ${ }^{46}$.
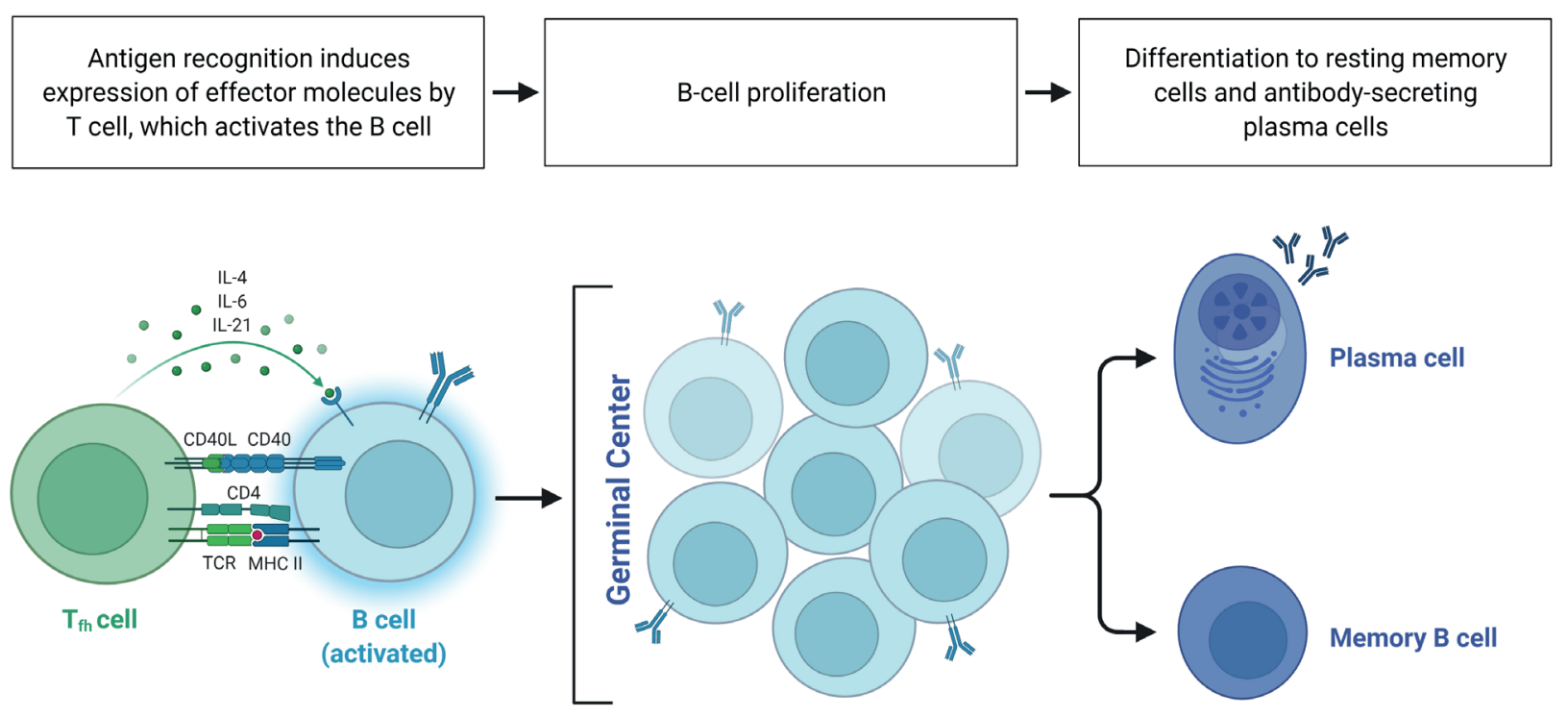

Figure 3. The germinal center reaction. The B cells proliferate faster once the GC response is initiated in a secondary lymphoid organ. In addition, some cells will change from immune response cells to pre-GC memory B cells. The remaining B cells initiate and participate in the GC reaction where iterative cycles of proliferation, mutation, and selection increase the average antigen-binding strength of the B cell receptors (affinity maturation). Some B cells will differentiate throughout the response into short-lived plasmablasts (secreting the now affinity-matured Abs), long-lived plasmablasts, and memory b cells. Image created using BioRender (https://biorender.com/) 


\section{SARS-CoV-2}

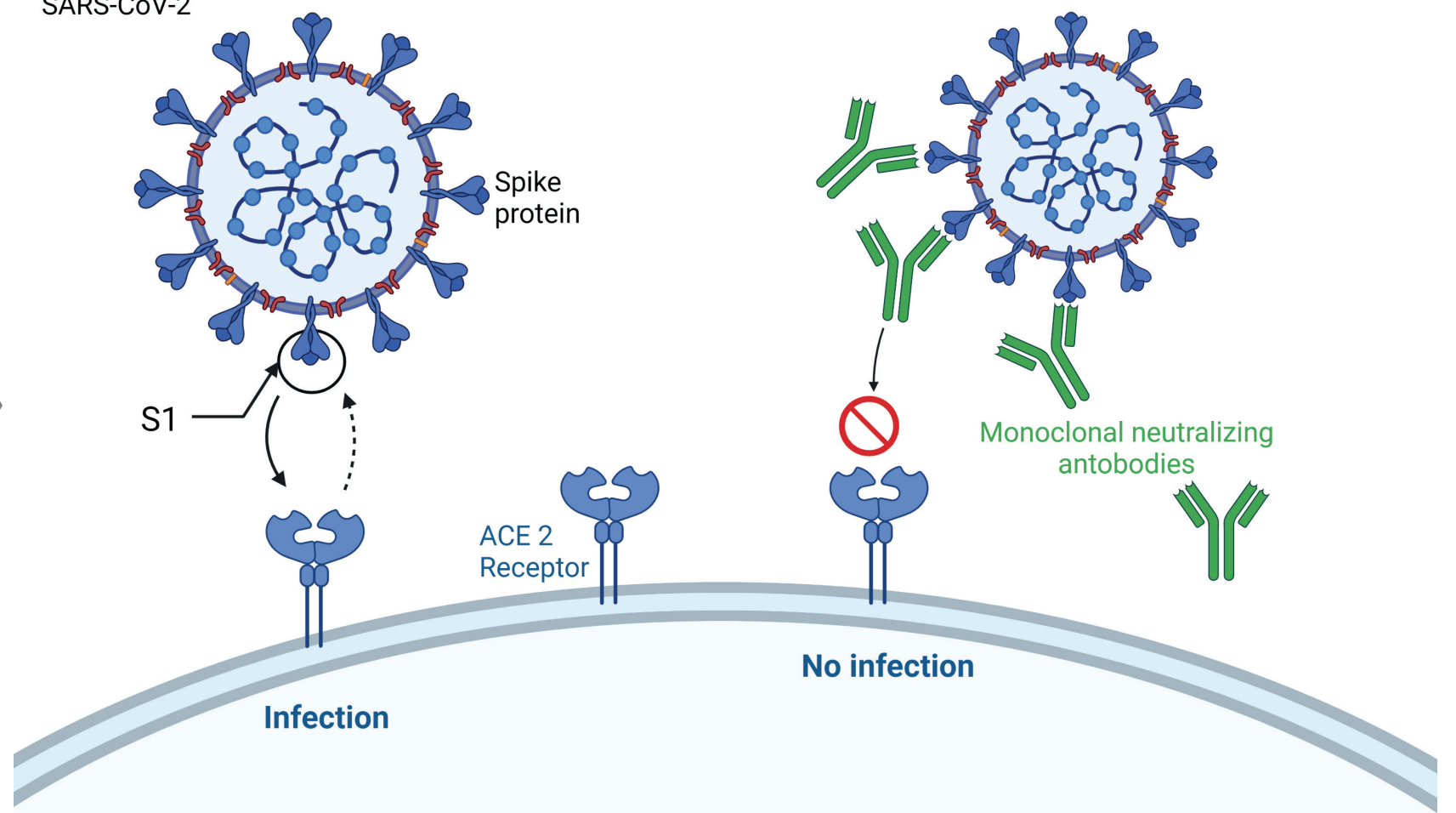

Figure 4. Monoclonal neutralizing antibodies. A functioning system of monoclonal antibodies binds to the virus's spike protein. These neutralizing antibodies prevent SARS-CoV-2 from binding to angiotensin-converting enzyme 2 (ACE2), resulting in decreased effectiveness of the virus. Image created using BioRender (https://biorender.com/).

These VOC include the Alpha Variant (B.1.1.7) lineage initially detected in the United Kingdom and spread worldwide ${ }^{47}$. Beta Variant (B.1.351) and Gamma Variant (P.1) lineages were detected in South Africa and Brazil, respectively ${ }^{48}$. These variants have several mutations and deletions compared to previously circulating viruses located in the receptor-binding domain (RBD). In December 2020, the Delta variant (B.1.617.2) was detected ${ }^{45}$. This variant caused many infections in the United States ${ }^{49}$ and India's second wave of infections ${ }^{50,51}$. In November 2021, the Omicron variant (B.1.1.529) was detected, causing multiple infections around the world ${ }^{52}$ (Figure 5).

Genomic surveillance of SARS-CoV-2 variants has primarily focused on mutations in the spike glycoprotein, which mediates attachment to cells and targets neutralizing antibodies because the spike is the major viral antigen in the current vaccines. It is hoped that adequate protection may still occur despite a few changes at antigenic sites in SARS-CoV-2 variants because current vaccines provoke an immune response to the entire spike protein ${ }^{53}$. The generation of powerful and long-lasting antibodies through the induction of long-lived memory B cells and plasma cells is the key to a vaccine's effectiveness. The antibody response provides a continuous supply of high-affinity antibodies that circulate and test our bloodstream and mucosal surface ${ }^{54}$.

A recent study identified a new monoclonal antibody (S2X259) with broadly neutralizing effects targeting a highly conserved $\mathrm{RBD}$ region called antigenic site $1{ }^{55}$. This region is usually inaccessible because of the RBD conformation, and therefore a low fraction of antibodies generally target this site in infected individuals. S2X259 reacted with 29 of 30 S proteins of arboviruses, including SARS-CoV-2 and its new variants. The study demonstrated its broad applicability as a broadly neutralizing antibody because it showed the cross-reactivity of S2X259 with bat arboviruses. Alterations did not hinder the binding of this antibody in the RBD, which are present in the Alpha, Beta, and Gamma variants. The antibody binds to the epitope is conserved in all circulating SARS-CoV-2 variants. In addition, it does not target the 417 or 484 residues in new variants and, therefore, might explain its potency against different variants.

\section{Importance of vaccines}

For some time now, vaccines have become a preventive, routine, and effective measure to reduce the eradication rate or near eradication of certain viral diseases ${ }^{56}$. Furthermore, vaccines help in the creation of acquired immunity. Because a viral vector containing the information of the virus to be treated entered in the vaccine. If the virus enters the body, the immune system can attack it early. Also, vaccines prevent disease among vaccinated people. In addition, vaccines reduce infections even among people who are not vaccinated through herd immunity. Herd immunity happens if a sufficient proportion of the population is immunized or is immune to the virus ${ }^{57}$. Pharmaceutics can use the knowledge obtained in the realization of vaccines against SARS-CoV to develop and obtain vaccines for SARS-CoV-2. Since it has been observed that SARS-CoV-2 and SARS-CoV have significant similarities in their genomic sequences because they come from the same family and share a common cell receptor (ACE2) ${ }^{58,59}$. SARS-CoV-2 spike mRNA vaccines have been shown to mediate protection against severe disease, which can occur as early as ten days after the first vaccination when neutralizing antibodies are barely detectable ${ }^{60,61}$. Therefore, vaccine-induced CD8+ T cells may be the primary protection mediators at this early stage ${ }^{61}$.

The first two members of the Betacoronavirus genus, MERS and SARS, left us with experience and specific knowledge when designing vaccines to combat this type of virus. This facilitated the rapid response from scientists to start the de- 

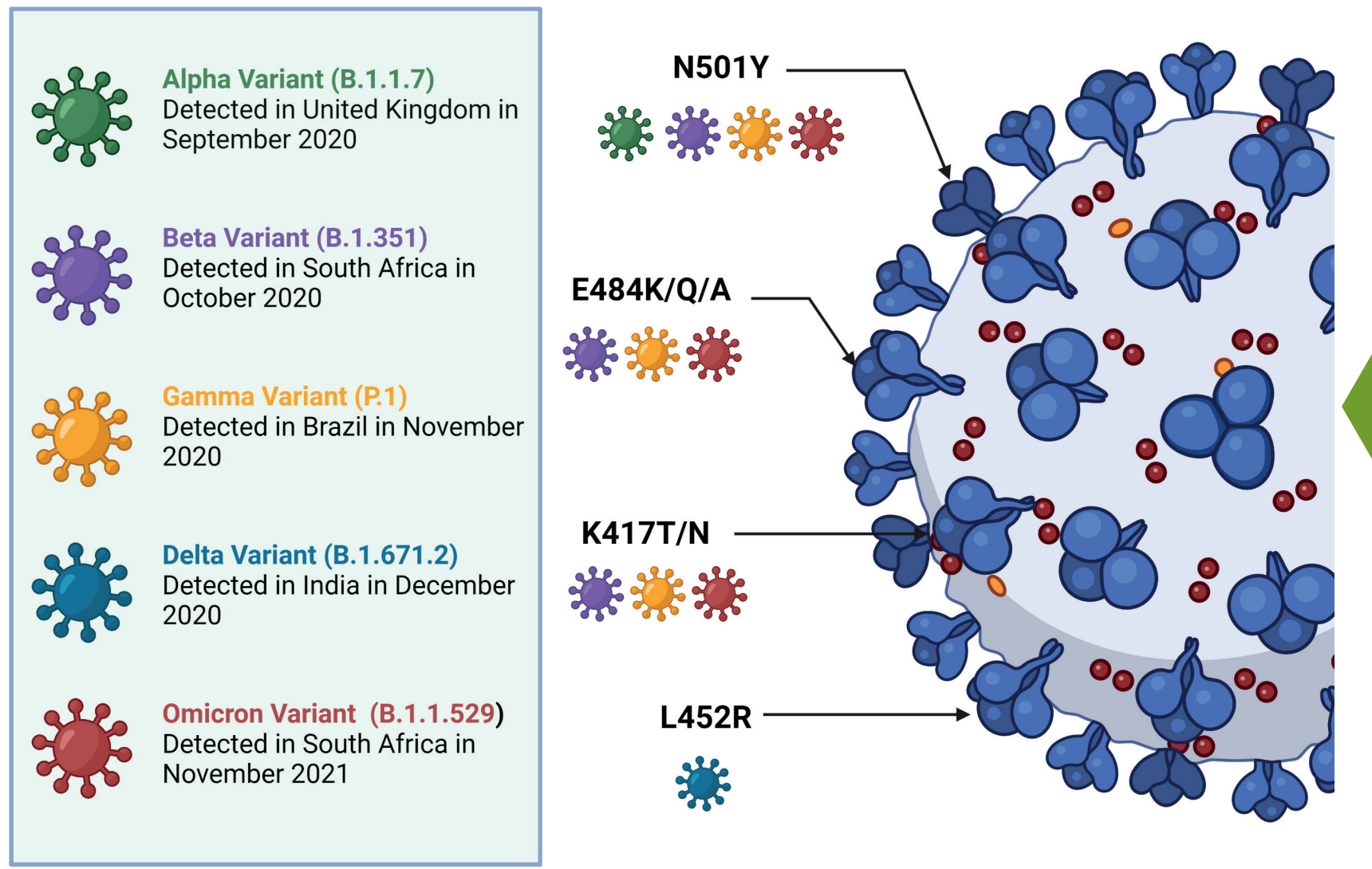

Figure 5. They are currently circulating SARS-CoV-2 variants of concern, and their receptor-binding domain (RBD) amino acid substitutions to virulence and immune evasion are relevant. The N501Y substitution is common to the Alpha, Beta, Gamma, and Omicron variant strains. The E484K/Q/A and K417T/N substitutions are present in the Beta, Gamma, and Omicron strains, while the L452R substitution is unique to the Delta variant. Image created using BioRender (https://biorender.com/).

velopment of the SARS-CoV-2 vaccines ${ }^{62}$. As we can observe in Table 1, scientists were based on 5 different leading platforms: RNA, DNA, Non-Replicant Viral Vector, Inactivated Viral Products, and Recombinant to develop the vaccines Protein Subunit. However, not all types of vaccines trigger the same immune responses in the body. Such is the case of LNP encapsulated mRNA and Inactivated vaccines, capable only of triggering the humoral immune response, representing a clear disadvantage if antibodies fail to detect emerging variants ${ }^{8}$.

\section{Multidose importance}

Almost all the Covid-19 vaccines approved to circulate worldwide were designed to require two doses to reach full efficacy ${ }^{69}$. The first clinical trials revealed that a pretty weak immune response was found after only one dose of the vaccine. Although it offers little protection against the virus, it can potentially lead to partial immunity, which drastically increases the risk that vaccine-resistant variants of SARS-CoV-2 emerge $^{70}$. On the other hand, the immune responses are more robust after completing the two-dose vaccine series and have shown sustained protection against new variants. One of the last documented examples is the delta variant, which has been reported a 33\% protection after a single shot of a two-dose Covid-19 vaccine, while individuals who completed the two-dose vaccine series reported a $90 \%$ protection against this variant ${ }^{69}$.

Lately, researchers have opted for a new strategy known as heterologous prime and boost. It gives a third dose (booster shot) of a different Covid-19 vaccine after 5-6 months of the second dose ${ }^{71}$. Studies have shown that persons over fifty years of age who took the booster shot had a 90\% lower mor- tality rate from Covid-19 than those who did not ${ }^{72}$. The reason behind this is that the neutralizing antibody responses were enhanced to such a level that they exceeded the estimated levels necessary to protect us from the virus. What remains uncertain is if this third dose will be enough to lengthen the protection gap or if this booster will become a standard measure to control population immunity ${ }^{73}$.

\section{Discussion}

An idea that has taken root in the population during the pandemic is that only by forming antibodies (humoral response) against SARS-CoV-2 will we be able to overcome the virus and the social consequences it has brought, but this is not entirely true. It is evident according to the literature data collected that, although at first, the researchers wanted to give a solution to Covid-19 by stimulating the generation of B antibodies through vaccines, with the arrival of new variants in increasingly shorter periods, they had to shift their focus to the cellular immune response ${ }^{70}$. This decision is because the $\mathrm{B}$ antibodies bind like a lock-and-key to spike proteins on the surface of the virus. However, these spikes are very susceptible to mutations; consequently, the B antibodies could become obsolete ${ }^{69}$, unlike what happened with the CD8+ T cells, which can target more than 15 distinct fragments of coronavirus proteins inside the infected cells. In this way, the next generation of Covid-19 vaccines will be dedicated to stimulating the cellular response more effectively provide more robust protection against emerging variants ${ }^{8}$. 


\begin{tabular}{|c|c|c|c|c|c|}
\hline Platform & Type of Vaccine & $\begin{array}{l}\text { Immune } \\
\text { Reaction }\end{array}$ & $\begin{array}{l}\text { Immune } \\
\text { Cells }\end{array}$ & Developer & Reference \\
\hline \multirow{3}{*}{ RNA } & $\begin{array}{l}\text { LNP encapsulated } \\
\text { mRNA }\end{array}$ & $\begin{array}{l}\text { Humoral } \\
\text { response }\end{array}$ & $\begin{array}{c}\text { Th1 } \\
\text { CD4+ T } \\
\text { cells }\end{array}$ & Moderna/NIAID & 63 \\
\hline & 3 LNP-mRNAs & $\begin{array}{l}\text { Humoral } \\
\text { and cellular } \\
\text { responses }\end{array}$ & $\begin{array}{c}\text { CD4+ T } \\
\text { cells, CD8+ } \\
\text { T cells }\end{array}$ & $\begin{array}{l}\text { Pfizer/BioNTech/Fo } \\
\text { sun Pharma }\end{array}$ & 63 \\
\hline & mRNA & $\begin{array}{l}\text { Humoral } \\
\text { and cellular } \\
\text { responses }\end{array}$ & $\begin{array}{l}\text { CD4+ T } \\
\text { cells, CD8+ } \\
\text { T cells }\end{array}$ & CureVac/Bayer & 63 \\
\hline \multirow{2}{*}{$\begin{array}{l}\text { Non- } \\
\text { Replicant } \\
\text { Viral } \\
\text { Vector }\end{array}$} & ChAdOx1-S & $\begin{array}{l}\text { Humoral } \\
\text { and cellular } \\
\text { responses }\end{array}$ & $\begin{array}{c}\text { CD4+ T } \\
\text { cells, CD8+ } \\
\text { T cells }\end{array}$ & $\begin{array}{c}\text { University of } \\
\text { Oxford/Astra Zeneca }\end{array}$ & 62 \\
\hline & $\begin{array}{l}\text { Adenovirus Type } 5 \\
\text { Vector }\end{array}$ & $\begin{array}{l}\text { Humoral } \\
\text { and cellular } \\
\text { responses }\end{array}$ & $\begin{array}{l}\text { CD4+ T } \\
\text { cells, CD8+ } \\
\text { T cells }\end{array}$ & $\begin{array}{c}\text { CanSino } \\
\text { BiologicalInc/ Beijing } \\
\text { Institute of } \\
\text { Biotechnology }\end{array}$ & 64 \\
\hline \multirow{3}{*}{$\begin{array}{l}\text { Inactivat } \\
\text { ed Viral } \\
\text { Products }\end{array}$} & Inactivated + alum & $\begin{array}{l}\text { Humoral } \\
\text { response }\end{array}$ & $\begin{array}{l}\mathrm{CD} 4+\mathrm{T} \\
\text { cells }\end{array}$ & Sinovac & 65 \\
\hline & Inactivated & $\begin{array}{l}\text { Humoral } \\
\text { response }\end{array}$ & $\begin{array}{l}\mathrm{CD} 4+\mathrm{T} \\
\text { cells }\end{array}$ & $\begin{array}{l}\text { Wuhan Institute of } \\
\text { Biological } \\
\text { Products/Sinopharm }\end{array}$ & 65 \\
\hline & Inactivated & $\begin{array}{l}\text { Humoral } \\
\text { response }\end{array}$ & $\begin{array}{l}\mathrm{CD} 4+\mathrm{T} \\
\text { cells }\end{array}$ & $\begin{array}{l}\text { Beijing Institute of } \\
\text { Biological } \\
\text { Products/Sinopharm }\end{array}$ & 65 \\
\hline \multirow[t]{2}{*}{ DNA } & $\begin{array}{l}\text { DNA plasmid vaccine } \\
\text { with electroporation }\end{array}$ & $\begin{array}{l}\text { Humoral } \\
\text { and cellular } \\
\text { responses }\end{array}$ & $\begin{array}{l}\mathrm{CD} 4+\mathrm{T} \\
\text { cells, CD8+ } \\
\mathrm{T} \text { cells }\end{array}$ & $\begin{array}{c}\text { Inovio } \\
\text { Pharmaceuticals/Inter } \\
\text { national } \\
\text { Vaccine Institute }\end{array}$ & 66 \\
\hline & DNA plasmid vaccine & $\begin{array}{l}\text { Humoral } \\
\text { and cellular } \\
\text { responses }\end{array}$ & $\begin{array}{l}\text { CD4+ T } \\
\text { cells, CD8+ } \\
\text { T cells }\end{array}$ & $\begin{array}{l}\text { Cadila Healthcare } \\
\text { Limited }\end{array}$ & 67 \\
\hline $\begin{array}{l}\text { Recombi } \\
\text { nant } \\
\text { Protein } \\
\text { Subunit }\end{array}$ & $\begin{array}{c}\text { Full length } \\
\text { recombinant SARS-CoV- } \\
2 \text { glycoprotein } \\
\text { nanoparticle Vaccine } \\
\text { adjuvanted with Matrix } \\
\text { M }\end{array}$ & $\begin{array}{l}\text { Humoral } \\
\text { and cellular } \\
\text { responses }\end{array}$ & $\begin{array}{l}\text { Th1 cells, } \\
\text { CD4+ T } \\
\text { cells, CD8+ } \\
\text { T cells }\end{array}$ & Novavax & 68 \\
\hline
\end{tabular}

Table 1. Immune response according to each type of vaccine.

\section{Conclusions}

The SARS-CoV-2 virus population is constantly evolving and will likely remain a part of our lives for many years to come. This virus has revolutionized the world economically and socially. This virus has revolutionized the world economically and socially. In addition, the development of vaccines against Covid-19 is related to immunological memory. To prevent Covid-19 disease and avoid transmission, the vaccine must elicit high titers of neutralizing antibodies. Memory T cells can fight infection if they have a high amount of neutralizing antibodies. Almost all vaccines against Covid-19 attack the spike protein. Older people have a poor T-cell response, so they risk severe Covid-19. Therefore, the elderly should be vaccinated so that the immunization provided by the vaccine occurs long before the infection, which allows the response, expansion, and maturation of the adaptive immune system.
Although the characteristics and functions of the virus have been deciphered during the last two years, there is still to investigate the relationships of SARS-CoV-2 with the severity of the disease, immunological memory, protection, and vaccines. However, studies of antigen-specific CD4+T cells, CD8+T cells, B cells, and antibodies together in larger cohorts of acute patients, representing a range of disease severity, are needed to understand protective adaptive immune responses mechanisms Covid-19 further. In addition, the scientific community must continue to improve surveillance and monitoring strategies to prevent these occurrences from having such damaging effects in the future. 


\section{Bibliographic references}

1. Liang $Y$, Wang M-L, Chien C-S, Yarmishyn AA, Yang Y-P, Lai W-Y, et al. Highlight of Immune Pathogenic Response and Hematopathologic Effect in SARS-CoV, MERS-CoV, and SARS-Cov-2 Infection. Frontiers in Immunology. 2020 May 12;11.

2. Poland GA, Ovsyannikova IG, Kennedy RB. SARS-CoV-2 immunity: review and applications to phase 3 vaccine candidates. The Lancet. 2020 Nov;396(10262):1595-606.

3. Harrison AG, Lin T, Wang P. Mechanisms of SARS-CoV-2 Transmission and Pathogenesis. Trends in Immunology. 2020 Dec;41(12):1100-15.

4. Suvvari TK, Kutikuppala LVS, Tsagkaris C, Corriero AC, Kandi V. Post囚COVID囚19 complications: Multisystemic approach. Journal of Medical Virology. 2021 Dec 28;93(12):6451-5.

5. Elias C, Sekri A, Leblanc P, Cucherat M, Vanhems P. The incubation period of COVID-19: A meta-analysis. International Journal of Infectious Diseases. 2021 Mar;104:708-10.

6. Domínguez N, Galocha A. Así es la lucha entre el sistema inmune y el coronavirus. EL PAÍS [Internet]. 2020 Apr 21 [cited 2022 Feb 5]; Available from: https:/elpais.com/elpais/2020/04/20/ciencia/1587379836_984471.html

7. Janeway C, Travers P, Walport M, Shlomchik M. Immunobiology: The Immune System in Health and Disease. 5th ed. Vol. 9. New York: Garland Science; 2001. 401-454 p.

8. Ledford H. 'KILLER'T CELLS COULD BOOST COVID IMMUNITY AMID NEW VARIANTS. Nature. 2021 Feb 18;590(7846):374-5.

9. Grifoni A, Weiskopf D, Ramirez SI, Mateus J, Dan JM, Moderbacher CR, et al. Targets of T Cell Responses to SARS-CoV-2 Coronavirus in Humans with COVID-19 Disease and Unexposed Individuals. Cell. 2020 Jun 25;181(7):1489-1501.e15.

10. Toor SM, Saleh R, Sasidharan Nair V, Taha RZ, Elkord E. T-cell responses and therapies against SARS-CoV-2 infection. Vol. 162, Immunology. Blackwell Publishing Ltd; 2021. p. 30-43.

11. Ahmadpoor P, Rostaing L. Why the immune system fails to mount an adaptive immune response to a COVID-19 infection. Vol. 33, Transplant International. Blackwell Publishing Ltd; 2020. p. 824-5.

12. Onder G, Rezza G, Brusaferro S. Case-Fatality Rate and Characteristics of Patients Dying in Relation to COVID-19 in Italy. Vol. 323, JAMA - Journal of the American Medical Association. American Medical Association; 2020. p. 1775-6.

13. Zelba H, Worbs D, Harter J, Pieper N, Kyzirakos-Feger C, Kayser S, et al. A Highly Specific Assay for the Detection of SARSCoV-2-Reactive CD4 + and CD8 + T Cells in COVID-19 Patients The Journal of Immunology. 2021 Feb 1;206(3):580-7.

14. Sette A, Crotty S. Adaptive immunity to SARS-CoV-2 and COVID-19. Vol. 184, Cell. Elsevier B.V.; 2021. p. 861-80.

15. Chen Z, John Wherry E. T cell responses in patients with COVID-19. Nature Reviews Immunology. 2020 Sep 1;20(9):52936.

16. Bacher P, Rosati E, Esser D, Martini GR, Saggau C, Schiminsky E, et al. Low-Avidity CD4+ T Cell Responses to SARS-CoV-2 in Unexposed Individuals and Humans with Severe COVID-19. Immunity. 2020 Dec 15;53(6):1258-1271.e5.

17. Wang D, Hu B, Hu C, Zhu F, Liu X, Zhang J, et al. Clinical Characteristics of 138 Hospitalized Patients with 2019 Novel Coronavirus-Infected Pneumonia in Wuhan, China. JAMA - Journal of the American Medical Association. 2020 Mar 17;323(11):1061-9.

18. Koutsakos M, Rowntree LC, Hensen L, Chua BY, van de Sandt CE, Habel JR, et al. Integrated immune dynamics define correlates of COVID-19 severity and antibody responses. Cell Reports Medicine. 2021 Mar 16;2(3)

19. Sette A, Crotty S. Adaptive immunity to SARS-CoV-2 and COVID-19. Vol. 184, Cell. Elsevier B.V.; 2021. p. 861-80.

20.Peng Y, Felce SL, Dong D, Penkava F, Mentzer AJ, Yao X, et al. An immunodominant NP105-113-B*07:02 cytotoxic $T$ cell response controls viral replication and is associated with less severe COVID-19 disease. Nature Immunology [Internet]. 2022 Jan 1;23(1):50-61. Available from: https://www.nature.com/articles/ s41590-021-01084-z
21. Peng Y, Mentzer AJ, Liu G, Yao X, Yin Z, Dong D, et al. Broad and strong memory CD4+ and CD8+ $T$ cells induced by SARS-CoV-2 in UK convalescent individuals following COVID-19. Nature Immunology. 2020 Nov 1;21(11):1336-45.

22. Nguyen THO, Rowntree LC, Petersen J, Chua BY, Hensen L, Kedzierski $L$, et al. CD8+ $T$ cells specific for an immunodominant SARS-CoV-2 nucleocapsid epitope display high naive precursor frequency and TCR promiscuity. Immunity. 2021 May 11;54(5):1066-1082.e5.

23. Pal N, Mavi AK, Kumar S, Kumar U, Joshi MD, Saluja R. Current updates on adaptive immune response by $\mathrm{B}$ cell and $\mathrm{T}$ cell stimulation and therapeutic strategies for novel coronavirus disease 2019 (COVID-19) treatment. Heliyon. 2021 Apr;7(4):e06894.

24. Gaebler C, Wang Z, C Lorenzi JC, Muecksch F, Finkin S, Tokuyama M, et al. Evolution of Antibody Immunity to SARS-CoV-2 12.

25. Quast I, Tarlinton D. B cell memory: understanding COVID-19. Vol. 54, Immunity. Cell Press; 2021. p. 205-10.

26. Aziz M, Brenner M, Wang P. Therapeutic Potential of B-1a Cells in COVID-19. Vol. 54, Shock (Augusta, Ga.). NLM (Medline); 2020. p. 586-94.

27. Aziz M, Holodick NE, Thomas •, Rothstein L, Wang • Ping. The role of $\mathrm{B}-1$ cells in inflammation. Immunologic Research. 2026;63.

28. Akkaya M, Kwak K, Pierce SK. B cell memory: building two walls of protection against pathogens. Vol. 20, Nature Reviews Immunology. Nature Research; 2020. p. 229-38.

29.Zhang LX, Miao SY, Qin ZH, Wu JP, Chen HY, Sun HB, et al. Preliminary Analysis of B- and T-Cell Responses to SARS-CoV-2. Molecular Diagnosis and Therapy. 2020 Oct 1;24(5):601-9.

30. Rombauts A, Stadlbauer D, Aslam S, Abelenda-Alonso G, Escalera $A$, Amanat $F$, et al. Antibody Immunological Imprinting on COVID-19 Patients.

31. Baumgarth N, Nikolich-Žugich J, Lee FE-H, Bhattacharya D. Antibody Responses to SARS-CoV-2: Let's Stick to Known Knowns. The Journal of Immunology. 2020 Nov 1;205(9):2342-50.

32. Victora GD, Nussenzweig MC. Germinal centers. Vol. 30, Annual Review of Immunology. 2012. p. 429-57.

33. Wajnberg A, Amanat F, Firpo A, Altman DR, Bailey MJ, Mansour $M$, et al. Robust neutralizing antibodies to SARS-CoV-2 infection persist for months. Science. 2020 Dec 4;370(6521):1227-30.

34.Piccoli L, Park YJ, Tortorici MA, Czudnochowski N, Walls AC, Beltramello $M$, et al. Mapping Neutralizing and Immunodominant Sites on the SARS-CoV-2 Spike Receptor-Binding Domain by Structure-Guided High-Resolution Serology. Cell. 2020 Nov 12;183(4):1024-1042.e21.

35. Robbiani DF, Gaebler C, Muecksch F, C Lorenzi JC, Wang Z, Cho $\mathrm{A}$, et al. Convergent antibody responses to SARS-CoV-2 in convalescent individuals. Nature. 2020;584:437.

36. Rogers TF, Zhao F, Huang D, Beutler N, Burns A, He W, et al. Isolation of potent SARS-CoV-2 neutralizing antibodies and protection from disease in a small animal model.

37. Jiang S, Hillyer C, Du L. Neutralizing Antibodies against SARSCoV-2 and Other Human Coronaviruses.

38. Putcharoen OI, Wacharapluesadee S, Ni Chia W, Paitoonpong L, Wah Tan C, Suwanpimolkul G, et al. 2 Thai Red Cross Emerging Infectious Diseases Health Science Centre World Health Organization Collaborating Centre for Research and Training on Viral Zoonoses. 2021;

39. Suthar MS, Zimmerman MG, Kauffman RC, Mantus G, Linderman SL, Hudson WH, et al. Rapid Generation of Neutralizing Antibody Responses in COVID-19 Patients. Cell Reports Medicine. 2020 Jun 23;1(3).

40.Liu L, Wang P, Nair MS, Yu J, Rapp M, Wang Q, et al. Potent Neutralizing Antibodies Directed to Multiple Epitopes on SARSCoV-2 Spike 12.

41. Andabaka T, Nickerson JW, Rojas-Reyes MX, Rueda JD, Bacic Vrca V, Barsic B. Monoclonal antibody for reducing the risk of respiratory syncytial virus infection in children. Vol. 2013, Cochrane Database of Systematic Reviews. John Wiley and Sons Ltd; 2013.

42. Mulangu S, E L, T R. A Randomized, Controlled Trial of Ebola Virus Disease Therapeutics. The new england journal of medicine. 2019 Dec;381:2293-303. 
43. Levine MM. E d i t o r i a I s Monoclonal Antibody Therapy for Ebola Virus Disease. 2019;

44. Medical Association A. Genetic Variants of SARS-CoV-2-What Do They Mean? 2021;

45. Mistry P, Barmania F, Mellet J, Peta K, le Strydom A, Viljoen IM, et al. SARS-CoV-2 Variants, Vaccines, and Host Immunity. 2019;

46.Prévost J, Finzi A. The great escape? SARS-CoV-2 variants evading neutralizing responses. Cell Host and Microbe. 2021 Mar 10;29(3):322-4

47. Andrew Rambaut, Nick Loman, Oliver Pybus, Wendy Barclay. Preliminary genomic characterisation of an emergent SARSCoV-2 lineage in the UK defined by a novel set of spike mutations. virological.org.. 2020 Dec;

48. Tegally H, Wilkinson E, Giovanetti M, Iranzadeh A, Fonseca V, Giandhari $\mathrm{J}$, et al. Detection of a SARS-CoV-2 variant of concern in South Africa. Nature. 2021 Apr 15;592(7854):438-43.

49. Brown CM, Vostok J, Johnson H, Burns M, Gharpure R, Sami S, et al. Morbidity and Mortality Weekly Report Outbreak of SARSCoV-2 Infections, Including COVID-19 Vaccine Breakthrough Infections, Associated with Large Public Gatherings-Barnstable County, Massachusetts, July 2021.

50. Mlcochova P, Kemp S, Shanker Dhar M, Papa G, Meng B, Mishra S, et al. SARS-CoV-2 B.1.617.2 Delta variant replication, sensitivity to neutralising antibodies 1 and vaccine breakthrough 23.

51. Cherian S, Potdar V, Jadhav S, Yadav P, Gupta N, Das M, et al. microorganisms SARS-CoV-2 Spike Mutations, L452R, T478K, E484Q and P681R, in the Second Wave of COVID-19 in Maharashtra, India. 2021;

52. WHO. Classification of Omicron (B.1.1.529): SARS-CoV-2 Variant of Concern. 2021.

53. Grubaugh ND, Petrone ME, Holmes EC. We shouldn't worry when a virus mutates during disease outbreaks.

54. Ecdc. Detection of new SARS-CoV-2 variants related to mink. 2020.

55. Alejandra Tortorici M, Czudnochowski N, Starr TN, Marzi R, Walls AC, Zatta F, et al. Broad sarbecovirus neutralization by a human monoclonal antibody. Nature. 2021:597:103.

56. Hajj Hussein I, Chams N, Chams S, el Sayegh S, Badran R, Raad M, et al. Vaccines Through Centuries: Major Cornerstones of Global Health. Vol. 3, Frontiers in Public Health. Frontiers Media S.A.; 2015.

57. Fisher KA, Bloomstone SJ, Walder J, Crawford S, Fouayzi H, Mazor KM. Attitudes toward a potential SARS-CoV-2 vaccine: A survey of U.S. adults. Vol. 173, Annals of Internal Medicine. American College of Physicians; 2020. p. 964-73.

58. Ma C, Su S, Wang J, Wei L, Du L, Jiang S. From SARS-CoV to SARS-CoV-2: safety and broad-spectrum are important for coronavirus vaccine development. Microbes and Infection. $2020 \mathrm{Jul}$ 1;22(6-7):245-53.

59.Zhou R, To KKW, Wong YC, Liu L, Zhou B, Li X, et al. Acute SARSCoV-2 Infection Impairs Dendritic Cell and T Cell Responses. Immunity. 2020 Oct 13;53(4):864-877.e5.

60.Polack FP, Thomas SJ, Kitchin N, Absalon J, Gurtman A, Lockhart S, et al. Safety and Efficacy of the BNT162b2 mRNA Covid-19 Vaccine. New England Journal of Medicine. 2020 Dec 31;383(27):2603-15.
61. Oberhardt V, Luxenburger H, Kemming J, Schulien I, Ciminski K, Giese $S$, et al. Rapid and stable mobilization of CD8+ T cells by SARS-CoV-2 mRNA vaccine. Nature. 2021 Sep 9;597(7875):26873.

62.Zandi M, Rashid S, Nasimzade S, Pourhossein B, Fazeli M. A Snapshot Of Different Types Of Under Research Vaccines A Gainst Covid 1 9: A Review. ARCHIVES OF MEDICAL LABORATORY SCIENCES. 2020;6(1).

63.Park JW, Lagniton PNP, Liu Y, Xu R-H. mRNA vaccines for COVID-19: what, why and how. International Journal of Biological Sciences. 2021;17(6):1446-60.

64.Zhu F-C, Li Y-H, Guan X-H, Hou L-H, Wang W-J, Li J-X, et al. Safety, tolerability, and immunogenicity of a recombinant adenovirus type- 5 vectored COVID-19 vaccine: a dose-escalation, open-label, non-randomised, first-in-human trial. The Lancet. 2020 Jun;395(10240):1845-54.

65. Jantarabenjakul W, Chantasrisawad N, Puthanakit T, Wacharapluesadee S, Hirankarn N, Ruenjaiman V, et al. Short-term immune response after inactivated SARS-CoV-2 (CoronaVac ${ }^{\circledR}$, Sinovac) and ChAdOx1 nCoV-19 (Vaxzevria ${ }^{\circledR}$, Oxford-AstraZeneca) vaccinations in health care workers. Asian Pacific Journal of Allergy and Immunology. 2023;

66. Andrade VM, Christensen-Quick A, Agnes J, Tur J, Reed C, Kalia $\mathrm{R}$, et al. INO-4800 DNA vaccine induces neutralizing antibodies and T cell activity against global SARS-CoV-2 variants. npj Vaccines. $2021 \operatorname{Dec} 14 ; 6(1): 121$.

67. Momin T, Kansagra K, Patel H, Sharma S, Sharma B, Patel J, et al. Safety and Immunogenicity of a DNA SARS-CoV-2 vaccine (ZyCoV-D): Results of an open-label, non-randomized phase I part of phase $\mathrm{I} / \mathrm{II}$ clinical study by intradermal route in healthy subjects in India. EClinicalMedicine. 2021 Aug;38:101020.

68. Keech C, Albert G, Cho I, Robertson A, Reed P, Neal S, et al. Phase 1-2 Trial of a SARS-CoV-2 Recombinant Spike Protein Nanoparticle Vaccine. New England Journal of Medicine. 2020 Dec 10;383(24):2320-32.

69. Crutcher M, Seidler PM. Maximizing Completion of the Two-Dose COVID-19 Vaccine Series with Aid from Infographics. Vaccines. 2021 Oct 22;9(11):1229.

70.Livingston EH. Necessity of 2 Doses of the Pfizer and Moderna COVID-19 Vaccines. JAMA. 2021 Mar 2;325(9):898.

71. Callaway E. MIXING COVID VACCINES TRIGGERS POTENT IMMUNE RESPONSE. Nature [Internet]. 2021 May 27 [cited 2022 Feb 7];593:491-491. Available from: http://myvax.com.s3.amazonaws.com/uploads/my_vax_article/article/d41586-02101359-3.pdf

72. Arbel R, Hammerman A, Sergienko R, Friger M, Peretz A, Netzer D, et al. BNT162b2 Vaccine Booster and Mortality Due to Covid-19. New England Journal of Medicine. 2021 Dec 23:385(26):2413-20.

73. Juno JA, Wheatley AK. Boosting immunity to COVID-19 vaccines. Nature Medicine. 2021 Nov 11;27(11):1874-5. 